\title{
PERUBAHAN SOSIAL KOMUNITAS SUKU ARFAK KABUPATEN PEGUNUNGAN ARFAK PAPUA BARAT
}

\author{
Therresse Nofianti*
}

\begin{abstract}
ABSTRAK
Perubahan-perubahan masyarakat berhubungan dengan perubahan nilai-nilai sosial, normanorma, pola perilaku organisasi, susunan lembaga kemasyarakatan, interaksi sosial. Kabupaten Pegunungan Arfak terbentuk sejak tahun 2012 melalui Undang-Undang Nomor 24 Tahun 2012 merupakan kabupaten induk yang kemudian dipecah menjadi Kabupaten Manokwari Selatan dan Pegunungan Arfak Masyarakat pegunungan Arfak disebut sebagai masyarakat suku besar Arfak karena terdiri atas beberapa sub suku yakni suku Hatam, Moile, Sough dan Meyah. Tulisan ini bertujuan untuk memberikan gambaran dan informasi mengenai perubahanperubahan sosial yang terjadi pada masyarakat suku Arfak di Kabupaten Pegunungan Arfak Propinsi Papua Barat. Metode yang digunakan berupa kajian pustaka dari berbagai laporan atau kajian ilmiah terkait dengan konteks perubahan sosial dan budaya pada masyarakat suku Arfak. Bahan-bahan tersebut dianalisis menggunakan teori-teori perubahan sosial Herbert Spencer, Talcot Parson, Teori modern Kingsley Davis (Transisi Demografis). Hasil yang diperoleh menunjukkan bahwa perubahan sosial pada masyarakat Suku Arfak di Kabupaten Pegunungan Arfak terjadi akibat adanya perubahan komposisi jumlah penduduk, adanya Kebijakan Otonomi Khusus Papua, masuknya inovasi baru, semakin mudahnya transportasi, program pemberdayaan, perubahan kelembagaan adat serta nilai dan norma yang memberikan dampak positif dan negatif pada kehidupan masyarakat.
\end{abstract}

Kata kunci: Perubahan Masyarajat, Papua Barat, Kabupaten Pegunungan Arfak, Suku Besar Arfak, Otonomi Khusus,

\begin{abstract}
Changes in society related to changes in social values, norms, patterns of organizational behavior, the composition of social institutions, social interaction. Arfak Mountains Regency formed since 2012 through Law Number 24 of 2012 is the main district which was later divided into South Manokwari Regency and Arfak Mountains. The Arfak mountain community is referred to as the large Arfak tribe because it consists of several sub tribes namely Hatam, Moile, Sough and Meyah. This paper aims to provide an overview and information about social changes that occur in the Arfak tribal community in the Arfak Mountains Regency, West Papua Province. The method used is a literature review of various reports or scientific studies related to the context of
\end{abstract}


social and cultural change in the Arfak tribal community. These materials were analyzed using Herbert Spencer's theories of social change, Talcot Parson, Kingsley Davis's modern theory (Demographic Transition). The results obtained show that social changes in the Arfak tribe in the Arfak Mountains District occur due to changes in the composition of the population, the existence of the Papua Special Autonomy Policy, the inclusion of new innovations, easier transportation, empowerment programs, changes in customary institutions and values and norms that have an impact positive and negative on people's lives.

Key words: Masyarajat Change, West Papua, Arfak Mountains Regency, Arfak Great Tribe, Special Autonomy,

\section{PENDAHULUAN}

Perubahan-perubahan masyarakat berhubungan dengan perubahan nilai-nilai sosial, norma-norma, pola perilaku organisasi, susunan lembaga kemasyarakatan, interaksi sosial dan lain sebagainya Soekanto (1990). Perubahan sosial dapat bermakna sebagai kemajuan ataupun kemunduran. Martono (2011), mengemukakan bahwa perubahan sosial berkaitan degan teori perspektif struktural fungsional. Pandangan tersebut bahwa masyarakat adalah sebuah sistem yang stabil dan memiliki tatanan sosial relatif stabil dan terintegrasi dalam kehidupan seharihari. Pada pandangan tersebut terlihat bahwa kestabilan dan keteraturan dalam kehidupan masyarakat dianggap sebagai kondisi dan situasi yang stabil dan perubahan yang terjadi dalam kehidupan masyarakat sebagai penyimpangan. Menurut perspektif struktural fungsional bahwa perubahan sosial diabaikan dalam kehidupan masyarakat dan masyarakat dalam kondisi yang statis atau tetap untuk melakukan aktivitas kehidupan. Dalam teori mengenai perubahan-perubahan masyarakat sering dipersoalkan mengenai perbedaan antara perubahan sosial dan perubahan kebudayaan. Perbedaan yang demikian itu, tergantung dari adanya perbedaan definisi antara pengertian tmasyarakat dan kebudayaan. Apabila perbedaan definisi tersebut dapat dinyatakan dengan tegas, maka dengan sendirinya perbedaan antara perubahan-perubahan sosial dan kebudayaan dapat diterangkan dengan jelas (Lumintang, 2015)

Pegaf merupakan Kabupaten yang sebagian besar wilayahnya masuk dalam kawasan Hutan Lindung (HL) dan Cagar Alam, yakni Cagar Alam Pegunungan Arfak (CAPA). Pemerintah RI di tahun 1992 telah menetapkannya menjadi kawasan Cagar Alam (CA) Pegunungan Arfak melalui keputusan Menteri Kehutanan No. 783/KptsII/1992 tertanggal 11 Agustus 1992. Dalam keputusan itu ditetapkan bahwa kawasan ini membentang seluas 68.325,00 hektar. Mencakup 8 wilayah Distrik seperti; Menyambouw, Membey, Hingk, Tanah Rubuh, Warmare, Manokwari Selatan, Ransiki dan Oransbari. Masyarakat pegunungan Arfak disebut sebagai masyarakat suku besar Arfak karena terdiri atas beberapa sub suku yakni suku Hatam, 
Moile, Sough dan Meyah. Suku Hatam yang mendiami pegunungan Arfak bagian utara yaitu Distrik Oransbari dan Ransiki, Suku Meyakh yang menghuni bagian barat, yaitu Distrik Warmare dan Prafi, Suku Sougb yang menghuni bagian selatan, yaitu Distrik Anggi; dan Suku Moile yang tersebar di bagian timur, yaitu Distrik Minyambouw Wilayah ini sebelumnya merupakan bagian dari Kabupaten Manokwari namun di Tahun 2012 yang lalu ditetapkan sebagai kabupaten pemekaran baru, terpisah dari wilayah kabupaten Manokwari berdasarkan Undangundang No. 24 tahun 2012 tanggal 16 November 2012 (BPS Kab Pegaf, 2017).

Tulisan ini mengkaji tentang perubahan sosial, apa saja perubahan sosial yang terjadi pada masyarakat suku Arfak, bagaimana perubahan sosial terjadi, apa saja faktor-faktor pendorong dan penghambat perubahan sosial tersebut. Tujuannya untuk memberikan gambaran dan informasi mengenai perubahan-perubahan sosial yang terjadi pada masyarakat suku Arfak di Kabupaten Pegunungan Arfak Propinsi Papua Barat.

\section{METODE PENELITIAN}

Metode yang digunakan dalam tulisan ini berupa kajian pustaka. Metode ini dilakukan untuk melihat berbagai laporan atau kajian ilmiah terkait dengan konteks perubahan sosial dan budaya pada masyarakat suku Arfak. Fokus kajian pustaka pada isu-isu perubahan sosial budaya. Kajian pustaka dilakukan secara online untuk publikasi yang tersedia baik peer review journal maupun yang bersifat grey literature (tesis atau disertasi), artikel popular dalam majalah, buku ilmiah popular dan laporan survey masyarakat suku Arfak. Data sekunder diperoleh melalui studi dokumen berupa laporan hasil-hasil penelitian sebelumnya, Undang-Undang, Peraturan-Peraturan, Keputusan Presiden, Instruksi Presiden, Keputusan Menteri, dan Peraturan daerah. Bahan-bahan tersebut kemudian dianalisis menggunakan teoriteori perubahan sosial Herbert Spencer, Talcot Parson, Teori modern Kingsley Davis (Transisi Demografis).

\section{PEMBAHASAN}

\section{Profil Kabupaten Pegunungan Arfak}

Kabupaten Pegunungan Arfak terbentuk sejak tahun 2012 melalui UndangUndang Nomor 24 Tahun 2012 tentang pembentukan Kabupaten Pegunungan Arfak di provinsi Papua Barat. Kabupaten Manokwari merupakan kabupaten induk yang kemudian dipecah menjadi Kabupaten Manokwari Selatan dan Pegunungan Arfak. Kabupaten Pegunungan Arfak terdiri dari sepuluh distrik dan ibukota kabupaten ini berkedudukan di Ullong Distrik Anggi (BPS, Kab Arfak, 2017).

Kabupaten Pegunungan Arfak memiliki batas wilayah sebagai berikut:

- Sebelah utara berbatasan dengan Kabupaten Manokwari;

- Sebelah timur Kabupaten Teluk Bintuni;

- Sebelah selatan berbatasan dengan Kabupaten Teluk Bintuni

- Sebelah barat berbatasan dengan Kabupaten Tambrauw

Dari segi luas wilayah menurut distrik, Testega merupakan distrik dengan wilayah paling luas (75.515 ha atau $19,65 \%$ dari luas 
wilayah Kabupaten Pegaf), diikuti distrik Catubouw (72.237 ha atau $18,80 \%$ dari luas wilayah Kabupaten Pegaf); sedangkan distrik dengan luas wilayah paling sempit adalah Membey (10.370 ha atau 2,37\% dari luas wilayah Kabupaten Pegaf), diikuti distrik Anggi (14.114 ha atau 3,67\% dari luas wilayah Kabupaten Pegaf). Dari segi fisiografi, distrik dengan persentasi wilayah paling banyak masuk dalam kategori extremly steep (sangat curam dengan kemiringan $>40 \%$ ) adalah Minyambouw
(73,83\%), diikuti oleh Membey (66,32\%); sedangkan distrik dengan flat (kategori berbukit dengan kemiringan $<2 \%$ ) dan very gentle (bergelombang dengan kemiringan 2 $8 \%$ ) adalah Anggi $(17,61 \%)$, diikuti oleh Taige $(8,91 \%)$. Data Profil Kabupaten Pegaf Tahun 2013 menyatakan bahwa hanya 20\% wilayahnya memiliki kemiringan $0-25^{\circ}$ (datar), selebihnya $80 \%$ wilayahnya memiliki kemiringan lebih dari $25^{\circ}$ (bergelombang/berbukit).

Gambar 1. Peta Kabupaten Pegunungan Arfak

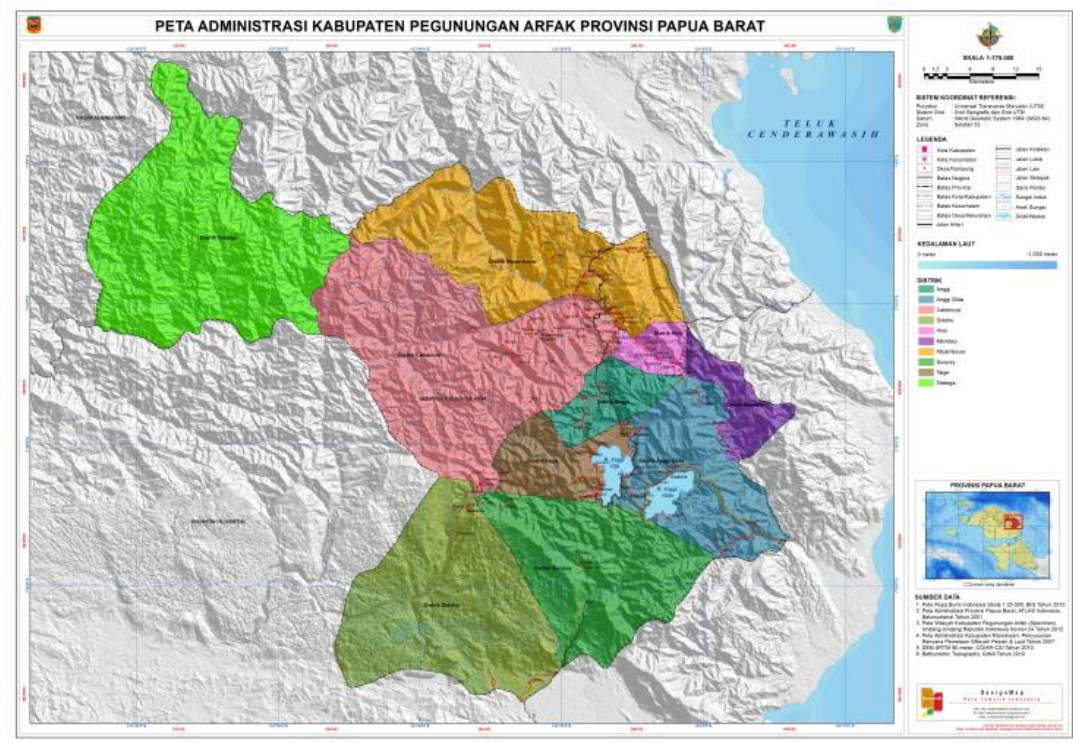

Sumber:https://petatematikindo.wordpress.com/2013/01/30/administrasipegunungan-arfak/

Peraturan Menteri Dalam Negeri Nomor 33 Tahun 20091 tentang Pedoman Pengembangan Ekowisata di Daerah, telah mendorong Pemerintah Daerah untuk mengembangkan ekowisata yang belakangan ini telah menjadi trend dalam kegiatan kepariwisataan di Indonesia. Kabupaten Pegunungan Arfak ditetapkan sebagai kawasan konservsi berdasarkan SK Kep. Menhut No.783/Kpts/Um/II/1992 dengan luas kawasan konservasi $68.325 \mathrm{Ha}$. Lebih lanjut pada Tahun 2015 Gubernur Provinsi Papua Barat Abraham O. Atururi mendeklarasikan Propinsi Papua Barat sebagai Propinsi Konservasi. Deklarasi ini, menunjukkan komitmen dari Pemerintah Papua Barat untuk memanfaatkan potensi kekayaan alam dengan tanggungjawab.1 Potensi wisata di Kabupaten Arfak terdapat di distrik Anggi berupa obyek wisata alam 
dan budaya, sedangkan obyek wisata di distrik Sururey dan Minyambouw, masingmasing memiliki obyek wisata budaya dan sejarah.

Jumlah objek wisata di Kabupaten Pegunungan Arfak pada kurun waktu 20132015 sebanyak 9 (sembilan) objek wisata, yang terdiri dari: 4 (empat) objek wisata alam, 2 (dua) objek wisata budaya dan seni, dan 3 (tiga) objek wisata air. Jumlah wisatawan dalam negeri dan luar negeri yang datang berkunjung selama tahun 2013 sampai tahun 2015 mengalami peningkatan dan kemajuan terutama wisata alam, banyak wisatawan berkunjung melihat burung cenderawasih, burung pintar, gua, gunung, daya tarik objek wisata tirta (wisata air) juga mengalami peningkatan terutama wisata danau anggi gida dan anggi gidi

\section{Perubahan Sosial Masyarakat Suku Arfak}

Perubahan sosial masyarakat suku Arfak terjadi dalam berbagai struktur dan sistem sosial masyarakat. Hasil penelitian Mulyadi (2016) menunjukkan bahwa ada nilai-nilai budaya yang memberi motivasi bertani kepada masyarakat Arfak dalam menjaga kelestarian alam dan semangat bekerja di kebun seperti pengetahuan rotasi kebun, menjaga hutan dan pola pertanian tumpangsari. Sebaliknya, ada juga nilai-nilai budaya yang ikut mengurangi motivasi bertani seperti bekerja keras di kebun untuk masa lalu dan mempersepsikan hidup di dunia buruk

Berdasarkan hasil pemetaan terhadap program intervensi pemberdayaan dan perlindungan perempuan memperlihatkan bahwa kondisi perempuan di wilayah perkotaan dan daerah coastal juga sudah mengalami perubahan yang cukup signifikan. Hal ini ditunjukkan dengan semakin terpenuhinya hak-hak perempuan di wilayah yang mengalami perubahan dibandingkan dengan kondisi perempuan di wilayah pedalaman/remote area. Perubahan positif ini bisa terjadi karena sebagian lakilaki telah memiliki kesadaran tentang pentingnya peran perempuan dalam kehidupan di masyarakat sehingga mereka cukup memberikan dukungan positif bagi perempuan (DAP, 2019).

Di Manokwari ditemukan perubahan yang positif menyangkut tersedianya infrastruktur kesehatan dan tenaga medis di tingkat kampung. Dulu perempuan melahirkan di hutan. Mereka tidak percaya proses kelahirannya dilakukan di rumah/kampung karena nanti sakit atau kena 'suanggi'. Dengan adanya upaya pendekatan dari tenaga kesehatan kepada masyarakat, perempuan Arfak mulai mengubah kebiasaan tersebut dan memilih melahirkan di rumah dan bahkan minta dijemput mobil untuk membawanya ke puskesmas. Temuan dari kajian lapangan di Manokwari, setelah otonomi khusus digulirkan sudah ada perubahan positif terkait jumlah perempuan Arfak yang ada di dalam struktur pemerintahan. Sudah ada yang menjadi kepala kampung dan kepala distrik, meskipun jumlahnya masih sangat minim. Perubahan penting lainnya yang telah terjadi adalah keberadaan LAPEPA (Lembaga Adat Perempuan Papua). Lembaga ini didirikan pada tanggal 21 Juli 2014 dan secara resmi dilantik oleh Gubernur Papua Barat pada tanggal 14 Desember 2015. 
Lembaga ini didirikan atas inisiatif sekelompok perempuan Papua yang ingin memperjuangkan suara perempuan baik di bidang politik, ekonomi dan sosial budaya. Selain itu, perubahan yang diharapkan terjadi tidak terlepas dari adanya keinginan untuk menegosiasikan nilai-nilai adat dan budaya lokal agar dapat adil dan melindungi perempuan dan anak. ${ }^{1}$

Pengembangan ekowisata CAPA turut membawa perubahan positif bagi masyarakat Arfak hal ini dapat dilihat dari segi ekonomi dimana masyarakat sekitar mendapat pendapatan tambahan, mereka yang dulunya hanya sebagai petani kini mendapat pekerjaan tambahan menjadi guide, pemerintah juga mendapat pendapatan dari pajak bangunan karena

Program pengembangan ekowisata di Kabupaten Pegunungan Arfak membuka peluang usaha baru bagi masyarakat, usaha homestay kepada turis asing maupun nusantara berupa jasa guide, potter dan tenaga pencari kayu bakar atau tanaman pertanian untuk dimakan oleh turis. Hal ini sejalan dengan Herbert Spencer yang menganut pandangan evolusi yang berkeyakinan bahwa kehidupan masyarakat tumbuh secara progresif menuju keadaan yang makin baik dan karena itulah kehidupan masyarakat harus dibiarkan berkembang sendiri, lepas dari campur tangan yang hanya akan memperburuk keadaan. Spencer menerima pandangan bahwa institusi sosial, sebagaimana tumbuhtumbuhan dan binatang, maupun beradaptasi secara progresif dan positif terhadap lingkungan sosialnya. Spencer juga menerima pandangan Darwinian bahwa proses seleksi alamiah, "survival of the masyarakat sekitar membangun penginapan untuk para wisatawan. Pemikiran Max Weber mengungkapkan bahwa manusia atau aktor merupakan makhluk kreatif, aktif, dan berfikir rasional ketika melakukan suatu tindakan. Perubahan sosial yang terjadi dalam kehidupan masyarakat karena masyarakat atau individu makhluk yang mampu untuk mengembangkan ide atau pemikiran atas tindakannya. Sorokin (1987), secara psikologis masyarakat potensial untuk berubah terutama yang berkenaan dengan tida aspek, yaitu: perubahan idea (ideational change), pengaruh unsur material terhadap mental manusia/masyarakat (sensational change), dan perubahan ideologi (idealistic change).

fittes" juga terjadi dalam kehidupan sosial. Lebih lanjut Astrd Susanto (1985), perubahan sosial terjadi sebagai hasil interaksi manusia untuk menyesuaikan diri dengan keadaan di sekelilingnya. Lebih lanjut Harris, faktor utama yang menyebabkan manusia berubah karena ekonomi yang tidak bisa mencukupi kehidupan sehari-hari. Faktor utama terjadinya perubahan sosial adalah keadaan geografi, keadaan biofisik kelompok, kebudayaan, dan sifat anomi manusia. Selain persewaan perahu usaha rumah penginapan juga meningkat. Fasilitas yang lain yang bisa menjadi peluang untuk meningkatkan pendapatan masyarakat adalah dengan membuka warung makan di disekitar homestay. Peluang kerja yang lain yang berpotensi dikembangkan di Cagar Alam Pegunungan Arfak adalah guide atau pemandu bagi wisatawan yang 
berpengetahuan baik yang saat ini masih minim (Sombait, 2010).

1 https://nasional.tempo.co/read/711098/pa pua-barat-deklarasikan-diri-sebagaiprovinsi-konservasi/full\&view $=$ ok

Pengembangan ekowisata CAPA juga membawa dampak negatif, ditemukan masih ada masyarakat yang membuang sampah ataupun berburu dan menebang pohon/ladang berpindah di sekitar kawasan Cagar Alam Pegunungan Arfak. Berbeda dengan hasil penelitian yang dilakukan Emma dan Rina (2014) tentang pengaruh ekowisata berbasis masyarakat terhadap perubahan kondisi ekologi, sosial dan ekonomi di kampung Batusuhunan, Sukabumi dimana pada aspek ekologi, penduduk telah memiliki kesadaran untuk melindungi lingkungan dengan membuang sampah pada tempatnya dan mulai menerapkan gaya hidup ramah lingkungan. Dalam aspek sosial, terjadi peningkatan kerjasama masyarakat terutama di bidang ekowisata. Kegiatan sosial di masyarakat sering diadakan sejalan dengan perkembangan ekowisata. Pada ekonomi, kesempatan kerja yang berasal dari sektor ekowisata bisa menjadi penghasilan tambahan bagi keluarga. Namun, perubahan dalam standar hidup tidak dapat dirasakan oleh masyarakat Batusuhunan karena pengembangan ekowisata baru saja dimulai dan baru berjalan selama sekitar 3 tahun.

Selanjutnya terdapat pergeseran nilai dalam banyak hal yang mempengaruhi kebiasaan ataupun tata kelakuan yang berlaku dalam masyarakat. Dalam masyarakat Arfak dikenal nilai-nilai Igya Ser Hanjop atau Mastogow Hanjop sebagai bentuk pengelolaan hutan. Istilah Igya Ser Hanjob (dalam Bahasa Hatam/Moile) atau Mastogow Hanjob (dalam Bahasa Soughb). Igya dalam Bahasa Hatam berarti berdiri; ser artinya menjaga; hanjob artinya batas. Secara harfiah, ig ya ser hanjob berarti menjaga batas namun bukan hanya bermakna sebagai suatu kawasan, tetapi mencakup segala aspek kehidupan masyarakat Arfak.

Secara filisofis, nilai-nilai tersebut mengandung makna bahwa segala sesuatu yang ada di alam ini (termasuk manusia) memiliki batas. Apabila batas tersebut dilanggar, maka akan terjadi bencana yang sangat besar. $^{2}$ Hal ini sejalan dengan tahap perkembangan pikiran manusia yang dicetuskan oleh Augute Comte yaitu tahap Teologis dimana tingkat pemikiran manusia yang beranggapan bahwa semua benda didunia ini mempunyai jiwa dan itu disebabkan oleh sesuatu kekuatan besar yang berada diatas manusia.

Di wilayah pegunungan Arfak terutama pada masyarakat sub-suku Hatam, kawasan hutan yang dimanfaatkan oleh masyarakat terbagi atas 4 (empat) bagian yakni susti, bahamti, nimahamti dan tumti (Laksono dkk. 2001, Salosa dkk. 2011). Bahamti adalah wilayah hutan primer yang tidak boleh diganggu sama sekali (wilayah perlindungan alam), wilayah ini merupakan kawasan hutan yang berlumut dan beberapa sangat curam, Nimahamti adalah kawasan hutan yang dapat dimasuki untuk mengambil kayu namun dengan jumlah yang terbatas dengan persetujuan kepala suku. Susti adalah kawasan yang diusahakan oleh masyarakat baik untuk tempat tinggal maupun untuk berkebun. sedangkan Tumti 
adalah bagian puncak gunung. Susti dan Nimahamti dapat difungsikan.sebagai kawasan penyangga jadi pemanfaatan hutan hanya bisa dilakukan pada kawasan ini. Situmorang (2013) menyebutkan bahwa keberadaan kawasan Bahamti, Nimahanti dan Susti saat ini telah mengalami perubahan karena adanya intervensi ekonomi, tekanan penduduk bahkan tekanan kebijakan politik.

2

https://id.wikipedia.org/wiki/Suku_Moile_d an_Suku_Meyah

Hal ini terlihat dari memudarnya perilaku masyarakat dalam menjaga dan mempertahankan keberadaan kawasankawasan tersebut. Dimana aktivitas berburu binatang dan aktivitas pertanian tradisional telah memasuki wilayah-wilayah yang dilarang secara hukum adat maupun hukum formal. Lebih lanjut Makabori (2005) menyebutkan bahwa telah terjadi pergeseran perilaku berupa penurunan kepatuhan masyarakat Arfak terhadap nilai-nilai Igya Ser Hanjop selama kurun waktu 20 tahun.

Perubahan sosial juga terjadi perubahan pada lembaga-lembaga kemasyarakatan suku Arfak. Salabai (2010) menyebutkan bahwa orang tua Arfak memiliki pola persepsi yang sama bahwa telah terjadi pergeseran nilai adat perkawinan hampir pada semua aspek, seperti pada aspek perjodohan dengan diterimanya budaya pacaran; mas kawin dengan bertambahnya jenis maskawin; prosesi perkawinan dengan adanya prosesi perkawinan singkat; pengurusan anak dengan adanya kecenderungan mengutamakan anak sendiri daripada anak saudara; hak waris dengan peniadaan hak waris untuk perempuan; poligami dengan adanya penolakan terhadap tradisi poligami dan perceraian dengan banyaknya kasus perceraian yang terjadi. Respon orang tua Arfak terhadap fenomena pergeseran nilai adat perkawinan Suku Besar Arfak menunjukkan pola respon yang berbeda. Sebagian orang tua Arfak tetap bersikukuh mempertahankan dan melaksanakan nilai adat perkawinan Arfak. Sebagian orang tua Arfak yang lain menerima perubahan atau penambahan selama tidak meninggalkan prinsip-prinsip yang pokok dalam adat perkawinan Suku Besar Arfak.

Dalam hubungannya dengan penerapan Hukum Positif atau UU No.1 Tahun 1974 tentang Perkawinan, persepsi orang tua Suku Besar menunjukkan pola yang berbeda. Pola persepsi pertama (diikuti sebagian besar orang Arfak) menunjukkan bahwa untuk melaksanakan perkawinan mereka tetap bersikukuh mempertahankan nilai adat perkawinan Suku Besar Arfak. Pola persepsi kedua, selain melaksanakan apa yang menjadi nilai adat perkawinan Arfak, mereka juga dapat mempertimbangkan urgensi UU Perkawinan karena pada dasarnya UU. Perkawinan banyak yang sejalan dengan ketentuanketentuan yang terdapat dalam nilai adat perkawinan Suku Besar Arfak.

\section{Faktor penyebab Perubahan Sosial Masyarakat Arfak}

Secara umum penyebab perubahan sosial dibedakan menjadi dua golongan besar, yaitu: perubahan yang berasal dari masyarakat itu sendiri dan perubahan yang berasal dari luar masyarakat (Soerjono, 
2009). Berdasarkan hasil review literatur diperolah perubahan masyarakat suku Arfak disebabkan karena beberapa faktor:

Pertama, bertambahnya jumlah penduduk. Pertumbuhan penduduk yang signifikan berdampak pada perubahan sosial kehidupan masyarakat. Pengaruh pertumbuhan penduduk terhadap perkembangan sosial di masyarakat diantaranya meningkatnya permintaan terhadap kebutuhan sandang, pangan,dan papan, berkurangnya lahan tempat tinggal, meningkatnya investor yang datang, pemerataan pembangunan dan sebagainya. Jumlah penduduk di Kabupaten Pegunungan Arfak tidak terlalu besar dibandingkan Kabupaten/ kota lain di Provinsi Papua Barat.

Berdasarkan Hasil Proyeksi Penduduk Tahun 2010, tercatat penduduk di Kabupaten Pegunungan Arfak mengalami peningkatan namun tidak pernah mencapai 30 ribu jiwa dalam periode 5 tahun terakhir. Dari sisi kinerja perekonomian, Kabupaten Pegunungan Arfak memiliki kecenderungan yang cukup positif. Selama kurun waktu 5 tahun terakhir, kinerja ekonomi Kabupaten Pegunungan Arfak selalu menunjukkan perbaikan dari tahun ke tahun. Hal ini ditunjukkan oleh nilai pertumbuhan ekonomi (PDRB) yang selalu bernilai positif.Pertambahan penduduk pada suatu daerah dapat mengakibatkan perubahan pada struktur masyarakat, terutama lembagalembaga kemasyarakatan. Peningkatan jumlah penduduk di Kabupaten Arfak mengakibatkan meningkatnya jumlah murid, guru, dokter, sarana dan prasarana masyarakat. Komposisi penduduk merupakan suatu perubahan sosial karena berkaitan dengan cara pembagian penduduk menurut kelompok usia, jenis kelamin, ras, etnik, jenis pekerjaan dan kelas sosial, sehingga mempengaruhi kehidupan sosial. Bertambahnnya jumlah penduduk mengakibatkan perubahan kelembagaan adat. Pergeseran nilai yang terjadi pada adat perkawinan Suku Besar Arfak juga disebabkan oleh semakin tingginya taraf pendidikan dan pengetahuan yang dimiliki masyarakat Arfak. Pesatnya kemajuan ilmu pengetahuan dan teknologi serta dampak modernisasi dan akulturasi budaya ikut memberikan andil dan kontribusi terhadap perubahan nilai perkawinan adat pada masyarakat Arfak.

Kedua, adanya Kebijakan Otonomi Khusus Papua, masuknya inovasi baru, dan semakin mudahnya transportasi. Banyak inovasi berupa kebijakan, program-program pemerintah yang masuk ke kampung masyarakat Arfak, baik yang dilakukan oleh Pemerintah melalui PPL, misionaris, dan LSM. Dimensi atribut inovasi yang diamati adalah: keuntungan, kesesuaian, kerumitan, kemudahan dicoba dan diamati, serta kemudahan diperolehnya. Dari enam atribut tersebut yang menonjol adalah bahwa inovasi memberi dampak keuntungan bagi kegiatan pertanian masyarakat etnis Arfak. Namun tidak terdapat sifat-sifat inovasi yang ditanggapi baik atau tinggi oleh masyarakat Arfak dilihat dari rendahnya lima atribut yang lain terutama inovasi yang tidak sesuai dengan sosial budaya masyarakat etnis. Hal tersebut menunjukkan bahwa inovasi yang diberikan selama ini hanya diadopsi sebagian atau diadopsi tetapi akhirnya ditinggalkan kembali; belum sesuai dengan kebutuhan, kebiasaan atau nilai-nilai sosial budaya yang masyarakat etnis Arfak miliki. (Mulyadi dan Deni, 2016) 
Pada suku Arfak adanya penerimaan terhadap unsur-unsur yang baru, dapat dilihat pada beralihnya mata pencaharian dari petani menjadi pelayan jasa pariwisata, dari petani menjadi pelaku industri kreatif, dari petani menjadi pedagang. Berikut adanya akulturasi yaitu dapat berbaur dengan masyarakat yang datang dari luar (wisatawan). Perubahan kebiasaan hidup dari tradisional ke semi modern dan adanya sikap menghargai hasil karya orang lain dan keinginan untuk maju. Menurut Rosana modernisasi dan perubahan sosial merupakan dua hal yang saling berkaitan. Modernisasi pada hakikatnya mencakup bidang-bidang yang sangat banyak, bidang mana yang diutamakan oleh suatu masyarakat tergantung dari kebijakan penguasa yang memimpin masyarakat tersebut. Modernisasi hampir pasti pada awalnya mengalami disorganisasi dalam masyarakat, apalagi yang menyangkut nilainilai dan norma-norma dalam masyarakat, dimana masyarakat yang bersangkutan belum siap untuk berubah, karena perubahannya begitu cepat serta tidak mengenal istirahat. Hal tersebut mengakibatkan disorganisasi yang terus menerus, karena masyarakat tidak pernah sempat untuk mengadakan reorganisasi.

Ketiga, faktor adanya kontak dengan kebudayaan lain dan faktor pendorong mengenai sistem terbuka dari lapisan masyarakat (open stratification), penduduk yang heterogen dan adanya nilai untuk meningkatkan taraf hidup. Hasil penelitian menemukan bahwasannya masyarakat setempat mengalami kontak dengan wisatawan meskipun hanya segelintir orang, karena wisatawan juga ingin mengetahui karakteristik yang unik, maka wisatawan berinterkasi dan melakukan kontak sosial dengan masyarakat setempat. Secara tidak langsung masyarakat melihat juga karakteristik dari wisatawan, sehingga adanya sebuah transformasi nilai sosial antara warga dengan wisatawan.

Sementara itu, faktor pendorong dan penghambat terjadinya perubahan senantiasa ada di setiap masyarakat. Perubahan sosial terjadi manakala faktor pendorong lebih kuat dari pada faktor penghambat. Sebaliknya, jika faktor penghambat lebih besar dari pada faktor pendorong maka perubahan sosial bisa terhambat bahkan tidak terjadi. Faktor pendorong terjadinya perubahan sosial adalah: sikap menghargai hasil karya orang lain, keinginan untuk maju, adanya toleransi terhadap perubahan yang menyimpang, sistem kemasyarakatan terbuka, penduduk heterogen, ketidakpuasan terhadap bidang kehidupan tertentu, sikap mudah menerima inovasi, adanya kontak dengan pihak lain, orientasi ke masa depan, dan nilai sosial yang mendukung upaya perbaikan nasib.

Faktor penghambat perubahan diantaranya adalah kurangnya sarana dan prasarana seperti sarana pendidikan, jaringan listrik, sarana transportasi dan sebagainya. Sedikitnya jumlah sekolah menyebabkan tingkat pendidikan di ini rendah. Kurangnya transportasi umum dan kondisi jalanan yang jelek menyebabkan masyarakat di distrik sulit melakukan mobilitas. Pemerintah pusat dan daerah tengah berupaya mengatasi permasalahan di Kabupaten Pegaf seperti yang dikatakan oleh Presiden Joko Widodo pada saat berkunjung ke Kabupaten Arfak bahwa:

"Yang akan saya prioritaskan adalah akses jalan untuk segera diaspal, sementara bandara saya minta waktu dua tahun untuk evaluasi, dan alhamdulillah bisa diselesaikan dalam waktu tersebut," ujar 
Jokowi dihadapan ribuan warga Pegunungan Arfak". ${ }^{3}$

Infrastruktur dasar utama yang segera diselesaikan adalah pengaspalan ruas jalan yang menghubungkan Kabupaten Pegunungan Arfak dengan Kabupaten Manokwari, sementara untuk fasilitas airport dibangun setelah pekerjaan jalan selesai. Jokowi mengatakan, akses jalan diprioritaskan, sehingga menunjang berbagai aktivitas masyarakat di sektor pertanian, ekonomi dan bisnis. Kabupaten Pegaf punya potensi pertanian daerah pegunungan yang melimpah, termasuk sektor pariwisata. Namun, selama ini terkendala di transportasi karena akses jalan belum diaspal secara keseluruhan. Masih kuat kepercayaan terhadap kekuatan gaib "swanggi" juga menjadi salah satu faktor penghambat perubahan social yang menyebabkan mereka takut beraktivitas di luar rumah.

3 https://nasional.tempo.co/read/1265083/j

okowi-janji-tuntaskan-infrastruktur-di-

pegaf-dalam-dua-tahun/full\&view $=$ ok

Pengembangan ekowisata di Kabupaten Arfak menimbulkan dampak positif dan dampak negatif terhadap terjadinya perubahan sosial di masyarakat. Hal tersebut dapat dilihat pada tingkat kesejahtraan masyarakat semakin meningkat. Masyarakat dapat mengikuti perkembangan ilmu pengetahuan dan teknologi, lapangan pekerjaan semakin kompetitif, fasilitas umum lebih tersedia, pemasaran hasil panen pertanian dapat dijual di tempat pariwisata. Dampak negatif dari pengembangan ekowisata di antaranya; perilaku masyarakat semakin konsumtif, kesenjangan sosial semakin tinggi, nilai-nilai tradisional semakin terkikis, keadaan lingkungan yang menjadi rusak dan lainlain. Perubahan sosial mempengaruhi berbagai aspek kehidupan, salah satunya dapat disebabkan oleh perkembangan arah perubahan social. Perubahan sosial selain dipengaruhi oleh faktor internal dan eksternal, juga dipengaruhi oleh faktor psikologis. Menurut Sorokin (Susanto Astrid 1985), faktor psikologis mempengaruhi dan mementukan arah perkembangan perubahan sosial (direction of change).

Menurut Selo Soemardjan dan Soelaeman Soemardi (1964) bahwa perubahan sosial bergerak meninggalkan faktor yang diubah. Akan tetapi setelah meninggalkan faktor tersebut, mungkin perubahan bergerak kepada sesuatu bentuk yang baru sama sekali, akan tetapi mungkin pula bergerak ke arah suatu bentuk yang sudah ada di dalam waktu yang lampau. Misalnya, proses modernisasi dan industrialisasi di Indonesia merupakan arah perubahan yang baru. Perubahan sosial yang memiliki arah kepada kemajuan adalah pembangunan. Pembangunan merupakan suatu proses perubahan sosial yang direncanakan dan dikehendaki. Tujuan pembangunan untuk memanfaatkan kemajuan teknologi dan ilmu pengetahuan, memperbaiki keadaan materi-materi manusia, agar dengan perbaikan ini martabat manusia dapat ditingkatkan (Susanto Astrid, 1985).

Modernisasi sebagai perubahan sosial dari keadaan yang tradisional, atau praindustri sebagai titik tolak perkembangan ke arah disederhanakan modernitas melalui transisi (peralihan). Dalam kehidupan 
masyarakat tradisional dapat dikatakan bahwa seluruh masyarakat memiliki jiwa yang tradisional pula. Sedangkan pada masyarakat peralihan (transisi) senantiasa memperhitungkan perubahan yang datang. Seringkali pada masyarakat ini terjadi salah menafsirkan konsep modern. Di mana setiap yang datang dan berasal dari luar (terutama berasal dari masyarakat Barat dan Eropa/ Amerika) kadangkala dianggap modern.

Masyarakat yang berjiwa modern menerima setiap perubahan yang bernilai positif dan menolak pengaruh yang bersikap negatif. Hal ini berkaitan dengan sikap rasionalitas yang dimilikinya dalam memilih dan menentukan perkembangan kehidupannya. Proses perubahan ke arah lebih maju dari sebelumnya yang ditunjang oleh sikap dan perilaku masyarakat untuk menerima perubahan-perubahan tersebut. Hal ini merupakan suatu proses ke arah kondisi modern yang dinamakan modernisasi. Dengan demikian, modernisasi dapat diartikan sebagai suatu sikap pikiran yang mempunyai kecenderungan untuk pendahuluan sesuatu yang baru dari pada yang bersifat tradisi, dan satu sikap pikiran yang hendak menyesuaikan soal-soal yang sudah menetap dan menjadi kebutuhankebutuhan yang baru. Dengan kata lain, modernisasi merupakan perubahan sosial yang terarah (directed change) yang didasarkan pada perencanaan (sosial planing). Gejala modernisasi merupakan awal terjadinya perubahan-perubahan ke arah yang diketahui. Misalnya: 1. sikap masyarakat tentang pentingnya pendidikan sekolah; 2. keinginan untuk hidup lebih baik; 3. adanya usaha untuk mengejar ketinggalan dari masyarakat lain; 4. menghargai pendapat orang lain; 5. tidak menganggap pendapatnya lebih baik dari orang lain; 6. memandang bahwa kehidupan hari esok harus lebih baik sari ini; dan lainlain. Berdasarkan pada terjadinya gejalagejala tersebut di atas, hal ini merupakan landasan bagi setiap masyarakat untuk melakukan perbaikan-perbaikan ke arah yang diharapkan dan dikehendaki.

\section{KESIMPULAN}

Perubahan sosial pada masyarakat Suku Arfak di Kabupaten Pegunungan Arfak terjadi akibat adanya perubahan komposisi jumlah penduduk, adanya Kebijakan Otonomi Khusus Papua, masuknya inovasi baru, dan semakin mudahnya transportasi, program pemberdayaan, perubahan kelembagaan adat serta nilai dan norma yang memberikan dampak positif dan negatif pada kehidupan masyarakat.

\section{DAFTAR PUSTAKA}

Abdulsyani, 1992, Sosiologi Skematika Teori dan Terapan, Jakarta, Bumi Aksara. Hlm. 10-36

Badan Pusat Statistik (BPS) Kabupaten Arfak. 2017.

Dewan Adat Papua (DAP). 2019. Narasi Perubahan. Sinergitas Para Pemangku Kepentingan dalam Upaya Pemberdayaan Perempuan Dan Perlindungan Anak di Tujuh Wilayah Adat di Tanah Papua. Kerjasaman dengan Kementerian Pemberdayaan Perempuan dan Perlindungan Anak Republik Indonesia (KPPPA RI) 
Emma Hijriati dan Rina Mardiana. 2014. Pengaruh Ekowisata Berbasis Masyarakat Terhadap Perubahan Kondisi Ekologi, Sosial dan Ekonomi di Kampung Batusuhunan, Sukabumi. Departemen Sains Komunikasi dan Pengembangan Masyarakat, Fakultas Ekologi Manusia, IPB ISSN: 2302 - 7517, Vol. 02, No. 03. Sodality: Jurnal Sosiologi Pedesaan | Desember 2014, hlm: 146-159

Lumintang Juliana. 2015. Pengaruh Perubahan Sosial Terhadap Kemajuan Pembangunan Masyarakat di Desa Tara-Tara I. e - journal "Acta Diurna" Volume IV. No.2. Tahun 2015

Makabori Yan. 2005. Pergeseran Igya Ser Hanjob Pada Masyarakat Lokal Di KAwasan Cagar Alam Pegunungan Arfak Kabupaten Manokwari. Sekolah Pascasarjana IPB. Bogor.

Martono, Nanang. 2011. Sosiologi Perubahan Sosial: Perspektif Klasik, Modern, Postmodern, dan Postkolonial. Jakarta: Rajawali Pers.

Mulyadi \& Deny A.Iyai. 2016. Pengaruh Nilai Budaya Lokal terhadap Motivasi Bertani Suku Arfak di Papua Barat. Fakultas Peternakan. Universitas Papua. Jurnal Peternakan
Sriwijaya Vol. 5, No. 1, Juni 2016, pp. 18 - 29. ISSN 2303 - 1093.

Salabai, Yakonias, 2010. Persepsi Dan Respon Ruang Tua Arfak Terhadap Pergeseran Nilai Perkawinan Adat Suku Besar Arfak Di Kelurahan Manokwari Barat Kabupaten Manokwari Papua Barat. Tesis. Ugm.

Situmorang Marel. 2013. Strategi Adaptasi Masyarakat Arfak Dalam Pengelolaan dan Pemanfaatan Sumberdaya Hutan di Cagar Alam Pegunungan Arfak. Skripsi. Fakultas Kehutanan. Universitas Papua.

Soemardjan Selo dan Soeleman Soemardi, 1974, Setangkai Bunga Sosiologi, Jakarta, Lembaga Penerbitan Fakultas Ekonomi Universitas Indonesia.

Susanto, S. Astrid. 1985. Pengantar Sosiologi dan Perubahan Sosial. Bandung. Binatjipta.

Soerjono Soekanto, 1990, Sosiologi Suatu Pengantar, Raja Grafindo Persada, Jakarta.

Undang-Undang Republik Indonesia Nomor 24 Tahun $2012 \quad$ Tentang Pembentukan Kabupaten Pegunungan Arfak Di Provinsi Papua Barat.

*Dosen Jurusan Sosial Ekonomi Pertanian, Fakultas Pertanian, Universitas Papua (Email: nofiantitherresse@gmail.com) 